\title{
Pembelajarannya
}

ISSN:2654-2587 (Print); ISSN:2654-735X (Online)

Volume 3, Nomor 2, Tahun 2020, Hal. 58-71

Available online at:

http://ejurnal.budiutomomalang.ac.id/index.php/alfabeta

\section{MEMAIN-MAINKAN MUKA SEBAGAI BENTUK EKSPRESI DALAM FILM MY STUPID BOSS: SEBUAH KAJIAN PRAGMATIK}

Ira Mayasari, Eko Yuliyanto

Pendidikan Bahasa Indonesia

Fakultas Bahasa dan Seni, Universitas Indraprasta PGRI

Jalan Nangka No. 58C, Tanjung Barat, Jagakarsa

bunazmina@gmail.com

\begin{tabular}{|c|c|}
\hline Informasi Artikel & ABSTRACT \\
\hline $\begin{array}{l}\text { Submit: } 4-05-2020 \\
\text { Diterima: } 18-10-2020 \\
\text { Dipublikasikan: } 31-10-2020\end{array}$ & $\begin{array}{l}\text { The study, entitled "Playing with the Face as a Form of } \\
\text { Expression in the Movie My Stupid Boss: A Pragmatic Study" } \\
\text { uses a descriptive qualitative method, with both listening and } \\
\text { note taking techniques. This study aims to describe the } \\
\text { subcategory playing with faces as a form of expression } \\
\text { performed by the cast in the movie My Stupid Boss. The } \\
\text { results of this study are that there are } 7 \text { subcategories, namely } \\
8 \text { acts of annoyance with cynicism, } 3 \text { acts of confusing with } \\
\text { rude commands, } 4 \text { insulth with ridicule, } 1 \text { utterance of teasing, } \\
5 \text { subcategories of belittling with cynisim, hurting feeling with } \\
\text { harshness for } 3 \text { utterances, and against with rejection of } 1 \\
\text { speech. } \\
\text { Keywords: Playing around face, Pragmatics }\end{array}$ \\
\hline Penerbit & ABSTRAK \\
\hline $\begin{array}{l}\text { Program Studi Pendidikan Bahasa } \\
\text { dan Sastra Indonesia } \\
\text { IKIP Budi Utomo, Malang, } \\
\text { Indonesia }\end{array}$ & $\begin{array}{l}\text { Penelitian berjudul "Memain-mainkan Muka sebagai Bentuk } \\
\text { Ekspresi dalam Film My Stupid Boss: Sebuah Kajian Pragmatik" } \\
\text { ini menggunakan metode deskriptif kualitatif, dengan teknik } \\
\text { simak dan catat. Penelitian ini bertujuan untuk mendeskripsikan } \\
\text { subkategori memain-mainkan muka sebagai bentuk ekspresi } \\
\text { yang dilakukan oleh pemeran dalam film My Stupid Boss. Hasil } \\
\text { dari penelitian ini adalah Terdapat } 7 \text { subkategori, yaitu tindakan } \\
\text { menjengkelkan dengan sinisme sebanyak } 8 \text { tuturan, tindakan } \\
\text { membingungkan dengan perintah kasar sebanyak } 3 \text { tuturan, } \\
\text { mencerca dengan ejekan sebanyak } 4 \text { tuturan, meledek dengan } \\
\text { gurauan sebanyak } 1 \text { tuturan, subkategori meremehkan dengan } \\
\text { sinisme sebanyak } 5 \text { tuturan, menyakiti perasaan dengan } \\
\text { keketusan sebanyak } 3 \text { tuturan, dan melawan dengan penolakan } 1 \\
\text { tuturan. } \\
\text { Kata kunci: alih kode, campur kode }\end{array}$ \\
\hline
\end{tabular}




\section{PENDAHULUAN}

Memain-mainkan muka merupakan bentuk ekspresi yang dilakukan oleh penutur kepada lawan tuturnya. Hal tersebut dilakukan untuk mempertegas maksud dari penutur agar pesan dapat tersampaikan dengan lebih jelas. Memain-mainkan muka, sering dilakukan seseorang untuk menyampaikan pesan tertentu. Misalkan, saat seseorang berbicara dengan intonasi marah, sedih, senang, ataupun lucu, mereka dapat memainkan muka dengan ekspresi yang berbeda. Ekspresi seperti itu hampir selalu terjadi dalam kehidupan sehari-hari. Misalkan, ketika lawan tutur ingin meminjam sesuatu kepada penutur, tetapi sebelumnya lawan tutur membuatnya kesal, ekspresi muka dan kalimat yang ke luar dari penutur tentunya berbeda. Jadi, bentuk memain-mainkan muka akan muncul ketika ada penyebabnya.

Objek dalam penelitian ini adalah film berjudul My Stupid Boss. Film My Stupid Boss disutradarai oleh Upi Afianto. Film berjenis komedi ini bercerita tentang hubungan kerja antara Boss yang absurd dengan karyawannya. "Bossman" (Reza Rahadian) adalah orang Indonesia yang memiliki perusahaan di Kuala Lumpur. Namun, perusahaannya itu tidak memiliki sistem dan aturan yang jelas sehingga sering membuat kariawannya merasa kebingungan.

Keunikan dalam film ini adalah penyebab dari semua kekacauan itu justru Bossman . Akan tetapi, Bossman memiliki semboyan "Bossman Always Right!". Jika Bossman memiliki kemauan, semua harus terwujud. Prinsipnya "Impossible We Do Miracle We Try". Diana (Bunga Citra Lestari) terpaksa terikat dalam hubungan kerja yang kacau setiap saat.

Menurut Mey (1994), seseorang yang ingin mengetahui pragmatik sebagai orang yang hendak mengetahui olahrahraga tertentu (Rahardi, dkk., 2016:1).Ilmu pragmatik didefinisikan oleh beberapa ahli, diantaranya Yule (1996:3) mendefiniskan pragmatik menjadi empat, yaitu (1) bidang yang mengkaji makna pembicara; (2) bidang yang mengkaji makna menurut konteksnya; (3) bidang yang melebihi kajian tentang makna; (4) bidang yang mengkaji ekspresi menurut jarak sosial yang membatasi partisipan yang terlibat dalam percakapan tertentu.

Pragmatik mengkaji makna yang dipengaruhi oleh hal-hal di luar bahasa (Kushartanti, dkk., 2005:104). Definisi mengenai pragmatik juga diungkapkan oleh beberapa ahli, seperti pendapat Morris (dalamPurwo) yang mengungkapkan bahwa pragmatik adalah telaah mengenai hubungan antara lambang dan penafsiran (1990:19). Menurut Verhaar, pragmatik adalah cabang linguistik yang membahas apa yang termasuk struktur bahasa sebagai alat komunikasi antara penutur dan pendengar dan sebagai pengacuan tanda-tanda bahasa pada hal-hal 'ekstralingual' yang dibicarakan (1996:14).

Leech (dalam Gunarwan, 2004: 2) melihat pragmatik sebagai bidang kajian dalam linguistik yang mempunyai kaitan dengan semantik. Adanya keterkaitan tersebut, dikenal dengan istilah semantisisme, yaitu melihat pragmatik sebagai bagian dari semantik; pragmatisisme yaitu melihat semantik sebagai bagian dari pragmatik; dan komplementarisme melihat semantik dan pragmatik sebagai dua bidang yang saling melengkapi.

Menurut Rahardi, dkk. (2016:95) ketidaksantunan berbahasa mencakup dua dimensi, yaitu dimensi wujud dan dimensi maksud (makna pragmatik). Berikut, lima kategori wujud dan maksud ketidaksantunan menurut Rahardi, dkk. (2016:5): (1) kesembronoan; (2) memain-mainkan muka; (3) melecehkan muka; (4) mengancam muka, dan (5) menghilangkan muka.

Memain-mainkan muka termasuk kategori ketidaksantuan berbahasa mengandung ciri bahwa mitra tutur cenderung dibuat merasa jengkel (Rahardi dkk., 2016: 110). Perilaku 
memainkan muka juga memiliki ciri unsur-unsur sinis, sindiran, cercaan, yang semuanya menunjuk pada perilaku yang menjengkelkan dan membuat bingung orang lain (Rahardi, dkk., 2016:11).Menurut Rahardi dkk.(2016:111) membagi kategori memain-mainkan muka dalam sub-subkategori berikut,(1) Memain-mainkan Muka Subkategori Tindakan Menjengkelkan dengan Sinisme: Memain-mainkan muka subkategori menjengkelkan dengan sinisme merupakan tuturan yang disampaikan oleh penutur dilandasi rasa kesal atau mendongkol, yang disebabkan oleh sifat atau tingkah laku seseorang (KBBI:2008); (2) Memain-mainkan Muka Subkategori Tindakan Membingungkan dengan Perintah Kasar:Memain-mainkan Muka Subkategori Tindakan Membingungkan dengan Perintah Kasar merupakan penyampaian celaan dengan perkataan yang sifatnya membuat mitra tuturnya tidak mengerti atau tidak jelas dengan maksud tuturan si penutur (KBBI:2008); (3) Memain-mainkan Muka Subkategori Mencerca dengan Ejekan: Memain-mainkan Muka Subkategori Mencerca dengan Ejekan merupakan tindakan tidak santun dengan menggunakan ejekan atau makian yang keras; (3) Memain-mainkan Muka Subkategori Meledek dengan Gurauan: Memain-mainkan Muka Subkategori Meledek dengan Gurauan merupakan bentuk-bentuk kebahasaan yang bernuansa jenaka; (4) Memain-mainkan Muka Subkategori Meremehkan dengan Sinisme; (5) Memain-mainkan Muka Subkategori Meremehkan dengan Sinisme merupakan penyampaian tuturan yang sifatnya merendahkan atau mengejek lawan tutur, bahkan penutur meragukan sifat kebaikan yang dimiliki mitra tuturnya (KBBI:2008); (6) Memain-mainkan Muka Subkategori menyakiti perasaan dengan Keketusan: Memain-mainkan Muka Subkategori menyakiti perasaan dengan Keketusan merupakan tuturan yang disampaikan dengan keras dan tajam atau lancang hingga dapat menyakiti perasaan mitra tutur (KBBI:2008); (7) Memain-mainkan Muka Subkategori Melawan dengan Penolakan: Memain-mainkan Muka Subkategori Melawan dengan Penolakan merupakan tuturan yang terjadi ketika seseorang menolak melakukan sesuatu, sedangan penolakan itu melanggar aturan atau norma.

Malinowski berpendapat bahwa untuk memahami ujaran harus diperhatikan konteks situasi. Berdasarkan analisis konteks situasi ujaran, aspek-aspek bermakna bahasa dapat dipecahkan sehingga aspek linguistik dan nonlinguistik dapat dikorelasikan. Inti dari teori konteks adalah (1) makna tidak terdapat pada unsur-unsur lepas yang berwujud kata, tetapi terpadu pada ujaran secara keseluruhan; (2) makna tidak boleh ditafsirkan secara dualis (makna dan acuan) atau secara trialis (kata, acuan, tafsiran), tetapi makna merupakan satu fungsi atau tugas yang terpadu dalam tutur yang dipengaruhi oleh situasi (Pateda, 2011:118).

Sejalan dengan pernyataan tersebut, Leech mengatakan bahwa konteks merupakan latar belakang pemahaman yang dimiliki oleh penutur maupun lawan tutur sehingga lawan tutur dapat membuat interpretasi mengenai apa yang dimaksud oleh penutur pada waktu membuat tuturan tertentu (Nadar, 2009:6--7). Dengan demikian, konteks berkaitan dengan lingkungan fisik dan sosial sebuah tuturan yang dimiliki oleh penutur dan lawan tutur dalam memahami makna.

Dalam memahami makna, ekspresi wajah juga menjadi salah satu penentu untuk memperjelas makna. Ekspresi wajah atau mimik dapat diartikan sebagai hasil dari salah satu atau lebih gerakan atau posisi otot pada wajah. Ekspresi wajah merupakan salah satu bentuk komunikasi nonverbal dan dapat digunakan untuk menyampaikan keadaan emosi dari seseorang kepada orang yang mengamatinya (https://id.wikipedia.org/wiki/Ekspresi wajah). 


\section{METODE}

Penelitian ini menggunakan metode deskriptif kualitatif. Penelitian ini menggunakan teknik simak dan catat (Sudaryanto, 1993). Teknik simak yang digunakan adalah teknik simak bebas libat cakap, yang berarti peneliti tidak dilibatkan secara langsung. Namun, hanya pemerhati calon data yang terbentuk dan muncul dari peristiwa kebahasaandi luar dirinya. Teknik catat untuk mencatat pada kartu data dan mengklasifikasikan data. Objek yang diteliti dalam penelitian ini adalah gambar dan trankrip percakapan dalam film My Stupid Boss. Laporan dalam penelitian ini berupa kutipan-kutipan data untuk memberikan gambaran penyajian laporan tersebut (Moleong, 2012:11).

\section{HASIL DAN PEMBAHASAN}

Deskripsi hasil analisis dalam film My Stupid Boss, sebagai berikut.

1. Bossman : Shikin! Gimana sih ini? Kok Andrian absen keluar jam 5 gini sih ini? Kok pas banget sih, hah? Seenaknya itu orang.

Kamu ngerti apa artinya gak?

Shikin : (menggelengkan kepala) Entah.

Konteks : Tuturan tersebut terjadi di kantor Bossman. Setelah selesai mewawancarai calon pekerja, Bossman keluar ruangan dan memeriksa daftar hadir, kemudian bertanya ke Shikin.

Aspek Kebahasaan: tuturan Bossman merupakan beberapa kalimat pertanyaan kemudian langsung bertanya ke Shikin, "Kamu ngerti apa artinya gak?" Tuturan tersebut merupakan ketidaksantunan karena seakan-akan meremehkan Shikin dan membuatnya bingung. Karena bingung, Shikin menjawabnya dengan jawaban, "Entah." Unsur suprasegmental dari kalimat tersebut berupa intonasi naik dan intonasinya tidak terputus. saat mengucapkan kalimat tersebut. Ekspresi muka dengan jidat berkerut, pandangan tajam sedikit ke bawah dan tidak jelas, sehingga menyebabkan Shikin bingung. Ketidaksantunan dalam tuturan ini merupakan memainmainkan muka subkategori menjengkelkan dengan sinisme.

2. Bossman : Loh, makanya kalau makan makanan yang bergizi toh Shikin. Jangan roti canai terus tiap hari. Itu artinya sebelum jam 5 dia udah selesai kerja, ngerti nggak? Potong gaji!Ini juga Azhari ini telat 2 menit ini, kenapa sih telat dua menit sih hah? Kok telat-telat gini sih! Potong loh ya, potong loh. Telat satu menit potong gaji 1 jam, 2 menit 2 jam. Udah gitu aja.

Shikin : Maaf saya tak paham apa Boss cakap tadi. Yang saya tahu potong gaji. Tadi itu ayat ape?

Konteks : Tuturan tersebut terjadi di kantor Bossman. Setelah selesai mewawancarai calon pekerja, Bossman keluar ruangan dan memeriksa daftar hadir, kemudian bertanya ke Shikin. Karena Bossman kesal, akhirnya Bossman mengucapkan tuturan yang kurang berkenan di hati Shikin.

Aspek kebahasaan: Tuturan yang diucapkan oleh Bossman, yaitu "Loh makanya kalo makan makanan yang bergizi toh Shikin. Jangan roti canai terus tiap hari." merupakan bentuk ketidaksantunan karenaberdimensi ejekan. 
Tuturan tersebut merupakan bentuk ketidaksantunan subkategori mencerca dengan ejekan. Hal itu ditujukan kepada kariyawannya, yaitu Shikin.

3. Bossman : Hush, berisik! (pergi, kemudian kembali melihat orang tak dikenali duduk dibelakang)

Itu ngapain sih orang, minta sumbangan? Kok diterima-terima sih? Kita itu nggak terima. Suruh pulang sana!

Kerani $\quad$ : Em..., Pak Pak Pak, bukan pak. Saya ke sini mau interview.

Konteks : Tuturan tersebut terjadi di kantor Bossman, yaitu saat Bossman berkomunikasi dengan Shikin, kemudian Bossman melihat ke belakang ada seorang perempuan yang dikira akan meminta sumbangan.

Aspek kebahasaan: Tuturan yang diucapkan oleh Bossman saat bertanya padaShikin, yaitu "Itu ngapain sih orang minta sumbangan? Kok diterima-terima sih? Kita itu ga terima. Suruh pulang sana!" merupakan ketidaksantunan subkategori meremehkan dengan sinisme. Dalam tuturan tersebut terkandung situasi meremehkan,merendahkan,atau mengejek lawan tutur. Hal tersebut karena Bossman tidak mengetahui latar belakang Diana,namun langsung menyimpulkan bahwa Diana adalah orang yang ingin meminta sumbangan. Bossman memainmainkan muka dengan kategori meremehkan, sedangkan orang yang dimain-mainkan mukanya adalah Diana. Sebagai respon dari perasaannya, Diana berusaha menjelaskan ke Bossman bahwa tujuannya datang ke kantor adalah untuk wawancara.

4. Bossman : Interview? Nggak ada.

Kerani : Saya istrinya Dika Pak. Kata suami saya bapak butuh orang.

Konteks : Tuturan tersebut terjadi di kantor Bossman. Saat itu, Bossman menjawab dengan sepele bahwa tidak ada wawancara. Namun, Diana menjelaskan bahwa kedatangannya arena mendapat informasi dari sang suami, yaitu teman Bossman bahwa di kantor tersebut membutuhkan pekerja.

Aspek kebahasaan: berdasarkan aspek kebasaan, tuturan yang disampaikan oleh Bossman termasuk ketidaksantunan subkategori menyakiti perasaan dengan keketusan. Hal itu bisa dilihat pada tuturan Bossman bahwa tidak ada wawancara. Pada komunikasi tersebut, orang yang dimainmainkan mukanya adalah Diana. Diana merasa kaget dan bingung karena Bossman tiba-tiba mengatakan tidakada wawancaradan disampaikan dengan keras dan tajam.. Akhirnya, Diana merespon dengan cara menjelaskan bahwa dirinya adalah istri Dika, teman Bossman saat kuliahdi Amerika.

5. Bossman : Masa sih kamu istrinya Dika?

Shikin : Iyelah Boss.

Konteks : Tuturan tersebut terjadi di kantor Bossman. Saat itu, Bossman meragukan bahwa Diana adalah istri dari Dika temanya saat kuliah di 
Amerika. Namun, Shikin menjawab tuturan tersebut bahwa Diana memang benar istri dari Dika.

Aspek kebahasaan: Tuturan "Masa sih kamu istrinya Dika?" merupakan bentuk ketidaksantunan subkategori meremehkan dengan sinisme. Bossman tidak percaya bahwa Diana adalah istri dari Dika. Orang yang dimainmaikan mukanya dalam tuturan tersebut adalah Diana. Namun,orang yang membenarkan bahwa Diana adalah istri dari Dika adalah Shikin.

6. Bossman : Yakin...?

Shikin : Yakin...

Bossman : Pasti?

Shikin : Pasti.

Bossman : Awas! (menyuruh Shikin minggir) Are you sure? (sambil berjalan mengelilingi Kerani)

Konteks : Pada saat Kerani datang ke perusahaan Bossman untuk melamar pekerjaan.

Aspek kebahasaan: Tuturan tersebut termasuk ketidaksantunan subkategori meremehkan dengan sinisme karena Bossman seakan0akan meremehkan dan tidak percaya bahwa Kerani adalah istri Dika (temannya).

7. Shikin : Iye la Boss. Dia ni istri Cik Dika.

Bossman : Sok tahu bener. Emang Dika itu suami kamu apa? Iya Iya Iyaa? (Shikin menggeleng)

Konteks : Di kantor Bossman. Saat itu, Shikin meyakinkan Bossman bahwa Diana memang benar istri Dika. Namun, Bossman tidak menyukai jawaban tersebut karena menurutnya itu bukan pertanyaan untuk Shikin.

Aspek kebahasaan: Tuturan ": Iye la Boss, dia ni istri cik Dika." Merupakan ketidaksantunan subkategori menjengkelkan dengan sinisme. Hal itu karena tuturan Shikin yang merupakan bawahan Bosman terus menjawab pertanyaan yang tidak ditujukan padanya. Dalam hal ini, orang yang dimain-mainkan mukanya adalah Bossman sehingga dia merespon dengan rasa kesal, yaitu "Sok tahu bener. Emang Dika itu suami kamu apa? Iya? Iya? Iyaa?"

8. Bossman : Maaf lho ya, ini saya bener-bener lupa ini. Aduh... Saya itu kan biasa ketemu orang-orang penting. Ya, bukanya kamu nggak penting. Tapi yang saya ingat Cuma hal-hal penting aja.

Konteks : di kantor Bossman, tepatnya ruangan Bossman, saat Diana diwawancara.

Aspek kebahasaan: tuturan tersebut termasuk ketidaksantunan berbahasa subkategori meremehkan dengan sinisme. Saat itu, Bossman menjelaskan bahwa Bossman benar-benar lupa dengan istri Dika, yaitu Diana. Akan tetapi, ketika menyampaikan ditambahkan dengan dirinya terbiasa bertemu dengan orang-orang penting dan yang diingat hanya hal-hal penting saja. Hal ini tentunya menggiring opini bahwa Diana bukanlan orang penting untuk Bossman karena 
lupa dengannya. Hal itu tentu saja membuat Diana merasa tidak nyaman.

9. Bossman : Dulu itu saya ingat lho. Dika itu pernah ngasih lihat foto kamu, tapi dulu kamu itu gembrot... banget. Makanya saya pangling.

Kerani : (diam, mendengarkan, kesal, dan heran).

Konteks : di kantor Bossman, tepatnya ruangan Bossman, saat Diana diwawancara. Aspek kebahasaan: Tuturan, “... dulu kamu itu gembrot banget" merupakan ketidaksantunan subkategori mencerca dengan ejekan. Saat itu, Bosman mengatakan bahwa secara fisik dilu Diana Gembrot (gendut). Hal itu membuat Diana tidak suka dan merasa bahwa Bossman mengejeknya. Meskipun saat itu Diana Diam, tapi raut wajahnya menunjukkan ketidaksukaannya dengan hal itu.

10. Bossman : Yak, sudah paham

Bossman : Yak, sudah paham tugasnya kamu apa? Jadi, kamu akan diposisikan sebagai Kepala Administrasi.

Kerani : (mengangguk)

Bossman : Kalau di Malaysia itu disebutnya Kepala Kerani yaa...

Diana : (mengangguk)

Bossman : : Apa coba? Ayo. Ke... (Boss mendiktekan)

Kerani : Ke...

Bossman : Ra...

Kerani : Ra...

Bossman : (Tertawa) Bukan kera lho ya. Ada ni-nya di belakang lho ya.

Kerani : (hanya bengong)

Bossman : Saya ini kalau dipikir-pikir lucu juga saya ini ya. Jadi nanti kamu mengepalai semua karyawan yang ada di sini. Bisnis saya ini besar sekali. Ada ekspor impor besi, ada alat berat, ada spare part mobil, bengkel mobil. Banyak, semuanya ada di sini. Di Indonesia ada, Singapura ada. (Kerani diam lalu mengangguk).

Kok diem? Mesti kaget. Kagum ya? Biasa emang kalau orang-orang kagum sama saya. (sambil tertawa). Eh, kamu panggil saya Bossman.

Kerani : Iya Pak, Bossman.

Konteks : di kantor Bossman, tepatnya ruangan Bossman, saat Diana diwawancara.

Aspek Kebahasaan : Tuturan "Bukan kera loh ya. Ada ni-nya dibelakang loh ya." Tuturan tersebut dilakukan oleh Bossman kepada Diana saat proses wawancara. Adanya ketidaksantunan subkategori meledek dengan gurauan terjadi karena seorang bos perusahaan yang sedang melakukan wawancara seharusnya tetap pada situasi formal. Namun, saat itu Bosman berubah dari situasi formal ke situasi nonformal. Hal itu membuat lawan tutur, yaitu Diana merasa ada hal yang aneh.

11. Bossman : Okey.

Kerani $\quad$ : Oke (Berdiri ingin meninggalkan ruangan).

Bossman : Eh mau ke mana? Buru-buru amat sih? Tunggu dulu dong. Kamu ada lagi nggak sih yang mau diomongin? Ini kalau nggak ada saya sibuk sekali lho ini. Kalau bisa sekarang kamu pulang, besok masuk.

Kerani : (kaget) 
Konteks : di kantor Bossman, tepatnya ruangan Bossman, saat Diana diwawancara.

Aspek kebahasaan: Tuturan "Kamu ada lagi ga sih yang mau diomongin? Ini kalo ga ada saya sibuk sekali loh ini. Kalo bisa sekarang kamu pulang besok masuk" merupakan bentuk ketidaksantunan memain-mainkan muka subkategori tindakan membingungkan dengan perintah kasar. Tuturan ini disampaikan oleh seorang bosperusahaan kepada kariyawan yang baru saja diterima untuk bekerja di perusahaannya. Respon dari lawan tutur, yaitu Dianaatau kerani adalah kaget dan bingung.

12. Kerani : Udah gitu, kalau ngomong nggak dipikirin dulu. Nyerocos terus... nyerocos terus.

Dika : Emang gitu orangnya.

Kerani : Kmu gimana sih?! Dari tadi ngomongnya itu terus, itu terus.

Dika : Yaa, habis emang gitu orangnya.

Konteks : Tuturan terjadi di apartemen Diana. Saat itu, Diana sedang berkomunikasi dengan suaminya. Diana meminta tolong kepada suaminya untuk membantu dirinya mengancingkan baju yang terletak di belakang.

Aspek kebahasaan : Tuturan tersebut mengandung ketidaksantunan memainmainkan muka subkategori menjengkelkan dengan sinisme, yaitu pada kalimat "Kamu gimana sih?! Dari tadi ngomongnya itu terus, itu terus." Tuturan itu diucapkan oleh Diana dan ditujukan kepada suaminya. Ketidaksantunan terjadi karena tuturan tersebut diucapkan oleh seorang isteri kepada suaminya.

13. Bossman : Eh, Kerani.

Kerani : Iya Pak?

Bossman : Catet. Catet. Nanti lupa. Ini soal Amir (salah satu karyawan).

Kerani : Ini Amir siapa ya Pak?

Bossman : Amir siapa ya? Eh Shikin, ini Amir siapa ya?

Shikin : Kak Amir itu, pekerja Bangladesh kite. Sekarang dia dah ta ade. Dia balik kampung.

Konteks : Tuturan tersebut terjadi di kantor Bossman,setelah mewawancarai Diana (Kerani) dan menerimanya bekerja. Bosmaan menyuruh Diana untuk mencatat salah satu kariyawan yang bernama Amir. Namun, Diana tidak mengerti seseorang yang dimaksud oleh Bossman karena baru diterima kerja.

Aspek kebahasaan: Tuturan "Catet.Catet. Nanti lupa!" merupakan tuturan ketidaksantunan memain-mainkan muka subkategori tindakan membingungkan dengan perintah kasar. Bentuk kebahasaan tersebut merupakan tuturan yang tidak santun karena diucapkan olehseorang bos kepada kariawan yang baru saja dikenalnya. Respon dari lawan tutur,yaitu Diana adalah kebingungan.Diana merasa bingung karena baru bergabung di perusahaan tersebut, tetapi Bosman langsung menyuruhnya untuk mencatat kariyawan 
yang bernama Amir. Namun, ketika Diana bertanya kembali tentang Amir siapa, Bossman malah lupa. Hal itu membuat Diana bingung. Dalam hal ini, Bossman memain-mainkan muka dan yang dimain-mainkan mukanya adalah Diana.

14. Bossman : Iya, yang itu. Ya, tolong. Apalagi saya mau bilang ini? Kamu ini suka potong pembicaraan saya sih. Saya lupa ini gara-gara kamu ini.Oh Iya (memukul meja) Ingat saya. Tolong telepon Amir, kamu ngomongnya baik-baik loh ke dia! Kamu ini judes sih! Ya jadi bilang gini (memperagakan dengan lembut). "Amir, kamu bisa nggak pulang akhir bulan ini? Soalnya lagi banyak kerjaan. Kebetulan Arul lagi sibuk. Gimana, bisa ya sebelum akhir bulan balik ya?" (Boss melihat ke Kerani sambil menunggu jawaban).

Kerani : Ya mana saya tahu. Saya kan bukan Amir.

Konteks : Tuturan tersebut terjadi di kantor Bossman. Saat itu, Bossman menyuruh Diana untuk menelpon Amir. Namun, sebelum menelpon, Bossman sudah marah-marah kepada diana karena lupa ingin berbicara tentang apa. Bossman menuduh Diana bahwa Dianalah penyebab Bossman lupa.

Aspek kebahasaan: Berdasarkan aspek kebahasaan, tuturan "Ya, tolong.. Apalagi saya mau bilang ini? Kamu ini suka potong pembicaraan saya sih, saya lupa ini gara-gara kamu ini. Oh iya! (memukul meja) Ingat saya. Tolong telepon Amir, kamu ngomongnya baik-baik loh ke dia! Kamu ini judes sih...." Merupakan bentuk ketidaksantunan memain-mainkan muka subkategori tindakan membingungkan dengan perintah kasar). Letak dari tindakan memain-mainkan muka subkategori menjengkelkan dengan perintah kasar adalah ketika Bossman menuduh Diana bahwa dirinya suka memotong omongan orang. Dilanjutkan saat Bossman menyuruh Diana untukmenelpon Amir, sekaligus menyuruh Diana untuk sopan dalam berbicara, ditambah dengan dengan mengatakan bahwa Diana judes. Hal itu jelas merupakan bentuk ketidakssantunan barbahasa, apalagi mereka baru saja saling kenal.

15. Bossman : Selamat pagi semuanya! Apa kabarnya? Ya, nggak usah dijawab ya, pasti semuanya baik-baik saja, saya yakin. Kelamaan nanti ya kalau jawab satu-satu ya? (Sambil memukul meja).Jadi maksud dan tujuan saya mengumpulkan kalian pagi hari ini adalah saya memberitahukan sesuatu yang sangat penting.

Mr. Ho : Ya lah... If you speak bahasa Indonesia, only you and Kerani understands. We don't understans! Berapa kali saya harus bagi tahu you. Kami tak paham apa yang you kata.

Bossman : Sst! Sudah, sudah, berisik! Tau bising nggak sih? You pikir I tak bisa speak english apa? Eh, 13 tahun loh saya di Amerika loh ya! Inget loh itu! Oke! (memukul meja lagi). Jadi, I... want to buy... a new... factory, BIG! Factory.

Konteks :Tuturan tersebut terjadi di kantor Bossman.Pada malam harinya, Bossman menelpon Diana (Kerani) bahwa besok harus datang pagi karena akan diadakan rapat yang dimulai pukul 09.00. Semua kariawan datang pagi. Namun, Bossman yang ditunggu-tunggu 
tidak kunjung datang. Setelah ditunggu sampai pukul 11.00, baru datang. Namun,kedatangannya membuat para kariawan kesal. Ditambah dengan ketidaksadaran Bosmann bahwa datang terlambat. Apalagi, diadakannya rapat ternyata hanya untukmembicarakan mimpi Bossman.

Aspek kebahasaan: maksud ketidaksantunan memain-mainkan muka subkategori tindakan menyakiti perasaan dengan keketusan. Halitu dibuktikan dengan adanya tuturan "Berisik! Tau bising gak sih? You pikir I tak bisa speak english apa? Eh, 13 tahun loh saya di amerika loh ya!" Tuturan tersebut tidak pantas diucapkan kepada lawan tutur. Tuturan tersebut semakin tidak santun ketika ditambahkan unsur suprasegmental berupa intonasi naik. Hal itu membuat lawan tutur merasa kesal dan sakit hati.

16. Mr. Kho $\quad$ : AC dah koyak. Kene beli baru. Iya, sudah tue.

Azhari : Jangan harap lah Mr. Kho. Air pun ia tak beli.

Bossman : Eh...eh...eh... Gak usah ikut komentar kamu. Siapa suruh komentar? Koyak...koyak...koyak opo sih koyak? Rusak maksudnya rusak? Suruh Bedul itu tho benerin.

Mr. Kho : I don't understand.

Konteks : Tuturan tersebut terjadi di kantor Bossman, tepatnya ruang kerja kariyawan. Saat itu, kariyawan mengeluhkan kondisi AC yang sudah lama rusak, tapi Bossman taka da niat untuk menggantinya karena tidak ingin keluar uang. Bossman tidak perduli, meskipun tiap hari kariyawannya bercucuran keringat. Saat para kariyawannya mengeluh, ternyata Bosman mendengar sehingga Bossman berkomentar ketus.

Aspek kebahasaan: Tuturan "Eh.. eh... eh... Gak usah ikut komentar kamu. Siapa suruh komentar? Koyak.. koyak.. koyak opo sih koyak? Rusak maksudnya rusak? Suruh Bedul itu loh benerin!" merupakan bentuk ketidaksantunan berbahasa memain-mainkan muka subkategori menyakiti perasaan dengan keketusan. Hal itu terlihat pada saat Bossman mengatakan, "Gak ikut komentar kamu. Siapa suruh komentar." Didukung dengan unsur suprasegmental, yaitu intonasi naik untuk menunjukkan ekspresi kesal.

17. Bossman : Bedu..., Bedul. Can fix it!

Mr. Kho : Ini tak boleh diperbaiki, it is too old.

Bossman: Oh... tua, setua Mr. Kho ya? Oh... iya iya iya.

Konteks : Komunikasi tersebut terjadi di ruang kerja kariyawan. Bossman merasa kesal karena kariyawannya mengeluh terus tentang kondisi AC yang rusak. Karena kesal, Bossmanmemanggil Mr. Kho dengan sebutan Bedul dan mengatakan bahwa AC itu tua, setua Mr.Kho.

Aspek kebahasaan: Ketidaksantunan dalamkomunikasi tersebut terlihat pada sebutan Mr.Kho menjadi Bedul. Selainitu, Bossman menanggapi pendapat Mr. Kho bahwa AC tersebut sudah tidak bisa diperbaikikarena terlalu tua. Mendengar pendapat Mr.Kho, Bossman malah mencerca Mr.Kho dengan ejekan bahwa AC itu setuaMr.Kho.tuturan itu merupakan ketidaksantunan memain-mainkan mukakategori 
mencerca dengan ejekan. Saat itu, Mr.Khojelasmerasa tidak senang. Namun hanyamenunjukkan muka kesal.

18. Adrian : Bos, apa kata kalau kite nak jimat uang, kita beli yang second hand bos? Ah..., saye ada tempat yang special with special price.

Bossman : Toko punya saudaramu ya? Kakek? Nnenek? Hah? Ipar, ipar?

Adrian : : Bos ni cakap apa tau, tak paham lah Bos.

Bossman : Oh..., jangan-jangan kerjaan sampingan ya? Tempe bener sih. (sambil berlalu)

Konteks : Di kantor Bossman, saat Andrian menyarakan Bossman untuk membeli AC second, namunBossman berburuk sangka kepada Andrian.

Aspek Kebahasaan: Tuturan, "Toko punya saudaramu, ya? Kakek? Nenek? Hah? Ipar, ipar?" dan tuturan, "Tempe bener, sih." merupakan ketidaksantunan memain-mainkan muka subkategori menyakiti perasaan dengan keketusan. Saat itu Bossman berbicara kepada Andrian dengan sangat ketus, nada tinggi, dan berburuk sangka kepada Andrian. Hal itu tentu saja menyakiti perasaan Andrian.

19. Bossman : Kerani... Kerani...

Kerani...Kerani...Kerani..., dipanggil dijawab dong. Kenapa nggak dijawab?

Kerani : Hehehehe... (tersenyum puas), rasakan pembalasanku.

Konteks : Dikantor Bossman, saat Kerani memulai pembalasan kepada Bossman karena merasa selalu dibuat kesal. Kerani membalas dengan cara memutus kabel speaker yang biasa digunakan Bossman untuk memanggil karyawannya. Jadi, saat Bossman memanggil karyawan, suaranya tidak terdengar sampai keluar.

Aspek kebahasaan: Pada tuturan ini, orang yang dimain-mainkan mukanya adalah Bossman. Bossman awalnya memanggil Kerani biasa saja. Namun, karena tidak ada respon, Bossman mulai marah dan memanggil berkali-kali. Hal itu wajar dilakukan oleh seorang bos kepada karyawan. Akan tetapi, dalamtuturanini,orang yang memain-mainkan muka adalah Kerani. Senyum dan tuturan,"Rasakan pembalasanku" yang ditujukan kepada seorang bos adalah tuturan memain-mainkanmuka subkategori menjengkelkan dengan sinisme.

20. Bossman : Ada meeting kan hari ini?

Kerani : Nggak ada Pak.

Bossman : Ada kan? Ada kan? Jam berapa? (sambil memainkan mata)

Kerani : Nggak ada Pak, yakin, sure, pasti. (sambil tersenyum puas)

Konteks : Di kantor Bossman, saat Bossman kedatangan tamu.Bossman ingin mengelak dengan beralasan bahwa ada meeting dan memeberi kode kepada Kerani supaya menjawab bahwa betul ada meeting. Namun, 
karena Kerani sengaja ingin membuat Bossman kesal, dia mengatakan bahwa tidak ada meeting.

Aspek kebahasaan: Dalam tuturan ini, Keranilah yang memain-mainkan muka dengan tuturan memein-mainkan muka subkategori menjengkelkan dengan sinisme. Kerani tidak membenarkan Bossman bahwa hariitu ada rapat meskipun Bossman sudah memberikan kode. Jadi, Bossman merasa kesal pada Kerani dan merasa malu kepada tamu karena ketahuan berbohong.

21. Kerani : Pergi!...Pergi!... Pergiii! (sambil memegang raket nyamuk).

Suami : Sayang... (berusaha menenangkan)

Kerani : Pergi!...Pergi!... Pergiii!

Bossman :Sampai bertemu di kantor besok ya. (sambil lari).

Konteks: : Di rumah Kerani. Saat itu, Kerani terbangun dari tidurnya karena Bossman datang ke rumahnya dan berjoget bersama Dika (suami Kerani). Kerani sangat marah dan menolak kedatangan Bossmandengan cara mengusinya menggunakan raket nyamuk untuk memukul.

Aspek kebahasaan: Tuturan, "Pergi!...Pergi!... Pergiii!" yang diucapkan oleh seorang karyawan kepada Bosnya jelas merupakan bentuk ketidaksantunan. Ketidaksantunan memain-mainkan muka ini masuk subkategori melawan dengan penolakan. Penolakan terjadi ketika Bossman datang ke rumah Kerani. Meskipun Bossman sudah minta maaf, Kerani tetapmengusirnya. Bahkan, Kerani mengabaikan suami ketika berusaha menenangkannya.

22. Bossman : Eh Kerani.

Kerani : Saya mau bicara Pak.

Bossman : Pa! Saya juga mau bicara sama kamu. Ayo ikut saya dulu. (ke Panti

Asuhan)

Konteks : Tuturan tersebut terjadi di kantor Bossman.saat itu Bossman mengajak Diana (Kerani) untuk berbicara, namun sebelum Bossman mengatakannya, Kerani sudah lebih dahulu mengatakan bahwa dirinya ingin bicara.

Aspek kebahasaan : Tuturan, "Saya mau bicara, pak." yang diucapkan oleh Kerani merupakan ketudaksantunan memain-mainkan muka subkategori berbicara menjengkelkan dengan sinisme.Diana (Kerani) berbicara menggunakan bahasa yang kurang sopan,dengan nada tinggi. Hal itu membuat Bossmancukupheran.

23. Bossman : Luar biasa memang. Hal-hal seperti ini itu, hal yang sanggup membuat saya bahagia. Merasa sangat tersentuh gitu lho kalian semuanya. Ingat ulang tahun saya. Luar biasa memang. Oke, untuk itu hari ini saya akan traktir! (semuanya diam, kecuali Kerani yang senyum-senyum)

: Traktir! (semua masih diam)

: Free Lunch!

Adrian : Yakin? 


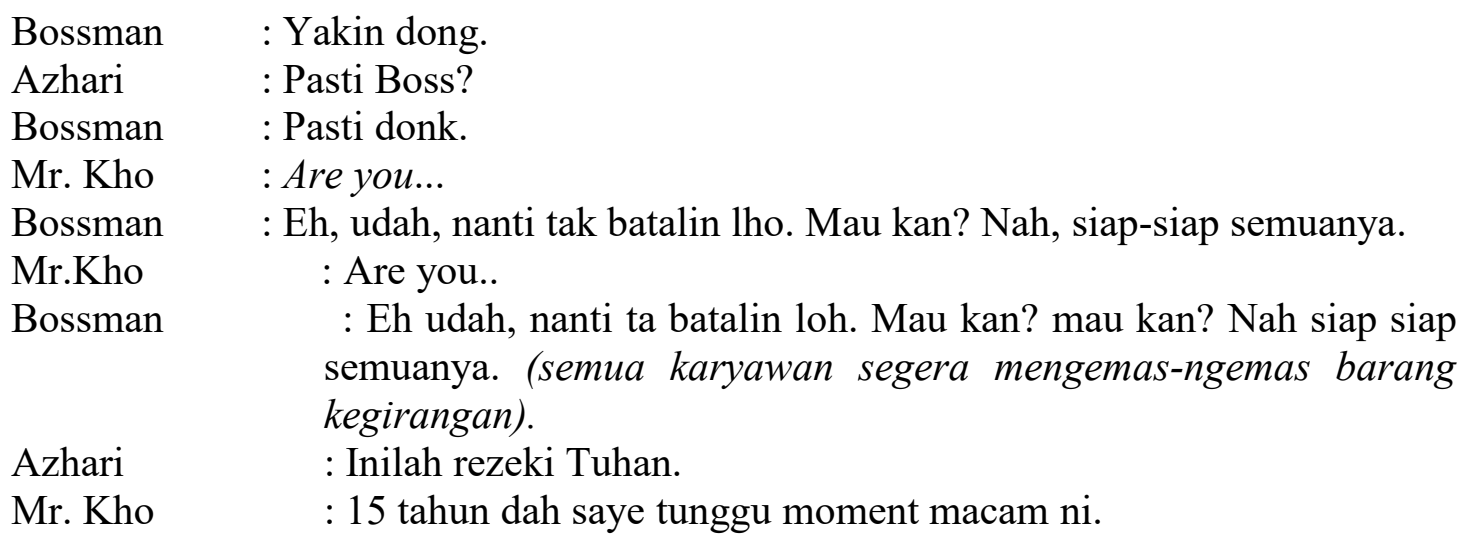

Konteks : Di kantor Bossman, saat Bossman tiba-tiba muncul dengan senyum-senyum karena dirinya sedang ulang tahun.

Aspek kebahasaan: Tuturan ketidaksantunan memain-mainkan muka kategori meremehkan dengan sinisme dilakukanoleh kariyawan Bossman, saat Bossman mengajaknya untuk makan gratis atau ingin mentraktir makan. Tuturan tersebut adalah jawaban, "yakin? dan pasti?" yang diucapkan oleh Andrian dan Shikin.

24. Kerani : Pak?

Bossman : Nggak ada duit.

Kerani : Saya nggak minta duit Pak.

Bossman : Jadi mau apa? Mau pinjam duit? Nggak ada, ini tanggal tua lho ini.

Konteks : Setelah sekian lama menunggu, Bossman tak kunjung keluar kantor. Mereka pun (kariyawan) memutuskan untuk mendatangi bossman di ruangannya. Namun,jawabannya benar-benar membuat semua kariyawan kesal. Bossman lupa kalau mengajak mereka makan-makan, mereka dikira ingin meminta uang. Bossman tetaplah Bossman.

Aspek kebahasaan : Tuturan, "Ga ada duit." dan "Jadi mau apa? Mau pinjam duit? Ga ada, ini tanggal tua loh ini." Merupakan ketidaksantunan memain-mainkan muka subkategori tindakan menjengkelkan dengan sinisme. Dalam hal ini, semua kariyawan dimain-mainkan mukanya oleh Bossman karena saat itu Bossman lupa kalau ingin mentraktir mereka.padahal mereka sudah menunggu cukup lama. Tuturan tersebut diucapkan dengan intonasi naik.

25. Kerani : Ini kita sebenernya jadi pergi apa nggak sih ini?

Bossman : Apaan sih pergi, pergi, pergi. Loh, eh, ini pada ngapain sih kok pada plonga-plongo di sini sih? Eh Shikin! Udah bawa tas? Jam berapa ini? Masih jam kantor lho ini. Sana, sana lanjut kerja. Gimana mau kaya, kerja aja males. Sana, sana! Kok tempe bener sih! (semua karyawan memasang muka marah)

Konteks : Saat Bossman lupa jika mengajak karyawannya untuk makanmakan.saat diingatkan,Bossman malah marah-marah. 
Aspek kebahasaan: Tuturan, “ Apaan sih, pergi, pergi, pergi! Loh eh, ini pada ngapain sih kok pada planga-plongo di sini sih...." merupakan ketidaksantunan memain-mainkan muka subkategori tindakan menjengkelkan dengan sinisme. Saat itu, Bossman membuat semua karyawan kesal dengan ucapannya karena belum ada satu jam mengajaknya makan,ternyata lupa. Bossman membuat meraka kesal karena juga menuduh malas bekerja.

\section{KESIMPULAN}

Penanda linguistik memain-mainkan muka, selain dilihat dari unsur segmental juga dilihat dari unsur suprasegmentalnya, seperti intonasi, nada, dan durasi. Penanda pragmatik ketidaksantunan sangat terikat dengan konteks tuturan. Terdapat 7 subkategori, yaitu tindakan menjengkelkan dengan sinisme, tindakan membingungkan dengan perintah kasar, mencerca dengan ejekan, meledek dengan gurauan, subkategori meremehkan dengan sinisme, menyakiti perasaan dengan keketusan, dan melawan dengan penolakan.

Dari ketujuh subkategori tersebut, memain-mainkan muka subkategori menjengkelkan dengan sinisme paling banyak ditemukan karena pada dasarnya, ciri khas memain-mainkan muka adalah membuat jengkel (kesal) orang lain. Selain itu, hal lainyang menjadi ciri khas memain-mainkan muka adalah adanya cercaan, unsur sinis, dan sindiran.

\section{DAFTAR PUSTAKA}

Leech, Geoffery. 2011. Prinsip-Prinsip Pragmatik. Jakarta: Universitas Indonesia.

Nababan, P.W.J. 1987. Ilmu Pragmatik (Teori dan penerapannya). Jakarta: Departemen Pendidikan dan Kebudayaan.

Nadar, F.X. 2009. Pragmatik dan Penelitian Pragmatik. Yogyakarta: Graha Ilmu.

Purwo, Bambang Kaswanti. 1990. Pragmatik dan Pengajaran Bahasa: Menyibak Kurikulum 1984. Yogyakarta: Kanisius.

Rahardi, Kunjana, dkk. 2016. Pragmatik Fenomena Krtidaksantunan Berbahasa. Jakarta: Erlangga.

Yule, George (Penerjemah Rombe Mustajab). 2014. Pragmatik. Yogyakarta: Pustaka Pelajae.

(https://id.wikipedia.org/wiki/Ekspresi_wajah). Diunduh tanggal 1 Desember 2019, pukul 21.30WIB.

(https://www.tribunnewswiki.com/2019/08/12)., diunduh tanggal 1Desember 2019, pukul 21.00 WIB.

71 Ira Mayasari dan Eko Yuliyanto, Memain-Mainkan Muka Sebagai Bentuk Ekspresi Dalam Film My Stupid Boss: Sebuah Kajian Pragmatik 